\title{
Strength of Timbers: A Case Study in Cambodia
}

\author{
Chhouk ChhayHorng ${ }^{1} *$ \\ ${ }^{1}$ Head of Civil Engineering Department, Institute of Technology of Cambodia, \\ Russian Federation Blvd, P.O. Box 86, Phnom Penh, Cambodia \\ *Corresponding author: horng@itc.edu.kh
}

\begin{abstract}
This study investigates the strength properties of timbers which are mostly used in the construction field in Cambodia. About 46 species of timbers selected from 4 categories of woods are tested in the laboratory of Institute of Technology of Cambodia. The tests are done to measure the compressive strength parallel to the grain, compressive strength perpendicular to the grain, tensile strength perpendicular to the grain, bending strength and shear strength of each species of timbers. At the meantime, the unit weight, density, humidity and moisture contents of timbers are also measured. The results from the experiments are found that the unit weight of lumbers is very different from one species to another. It could be observed that as the density increases, the various strength properties also increase. Some timbers resist very well under the ground like PHCHEK (Shorea Obtusa), some others resist better in water than others, for example KOKI (Hopea Odorata). The outcome of the study could help students, researchers, construction companies and architects to design and construct wood construction projects more economically, safely and appropriately. The results of this study can be additionally useful for future research and shared with other researchers in different institutions within the region.
\end{abstract}

Keywords - Strength of timber, Timber/Lumber/wood in Cambodia, Wood: density, axial tension, axial compression, shear, bending and perpendicular compression.

\section{INTRODUCTION}

Everywhere in the world, there are relatively large numbers of trees that are used to produce structural timber. Located in the tropical climate area with monsoon winds, which define two major seasons, hightemperature and humidity, Cambodia covered about 73 percent of the forestry in the 1970s and this amount have drop to 59 percent in 2006 [1]. In Cambodia, woods are distinguished into 4 categories such as luxury wood, first class wood, second class wood and third class wood. Wood is used for agricultural equipment use, energy, other purpose use and especially for the house construction. Mostly in the countryside of Cambodia, many buildings have been constructed with wood than with any other structural materials. Some provinces, districts and villages are called in the names of the trees. These show that the wood is quite important for Cambodian [2]. Compared with other construction materials, in term of mechanical properties, wood is similar to the concrete or steel. It is measured the compressive strength, tensile strength, shear strength and other properties of strength and characteristics [3].

Wood is one of the oldest and best-known structural materials, and one of the few renewable natural resources. Wood is a desirable material for construction because it requires less energy to produce a usable end product than do other materials. Wood is also extremely versatile. Because wood has a wide range of physical and mechanical properties, species can be selected on the basis of how well they fit the requirements for a particular product [4]. Different from other construction materials, wood is a special one because it grows naturally. Its mechanical properties largely depend on the species, age, location, climate and humidity. Related to its physical properties, wood has different colors and odors. The lumber of some species may be white, black, red, yellow, orange, purple, brown, and green. In addition, its unit weight, strength, density moisture content, and other characteristics are also different. The ability of wood to resist loads depends on a number of factors, including the type, direction, and duration of loading; ambient conditions of moisture content and temperature. The strength properties of wood are of importance in structural design. They are measure of the ability of wood to resist externally applied force which tends to alter its shape, size or result in any other deformation. Mechanical properties determine the applicability of wood in structure as well as many other uses where resistance to bending, compression, tension, shear and other effect of external force is required [5].

During1930s, a research study conducted by a group of French colonial engineers investigated the wood in Cambodia, Vietnam and Laos. The study investigated more than 52 species of wood on the physical characteristics, mechanical characteristics and use of 
wood. In terms of the mechanical properties, the study measured the axial compression and bending.

From the author's knowledge, it is observed that there is a limit studies that have been conducted to measure the strength properties of timbers including compressive strength, bending, tensile strength, shear strength and other characteristics of wood in Cambodia. Thus, there is still a research gap to further investigate both mechanical and physical properties of wood in Cambodia.

This paper aim to present the measurement of the strength properties of timbers selected from four groups of woods which is mostly used in construction field in Cambodia. In addition, the study also investigates the characteristics of timbers such as unit weight, density and moisture content of wood. The results of this study can be additionally useful for future research and shared with other researchers in different institutions within the region.

\section{METHODS}

\section{A. Experiments}

This study measures the strength properties of timber. Similarly to the concrete, timber is tested: compressive strength, tensile strength, shear strength and so on. In this study, we investigate the following strength properties of timbers:

1. Compressive strength parallel to the grain

2. Compressive strength perpendicular to the grain

3. Tensile strength perpendicular to the grain

4. Bending

5. Shear strength

1. Compressive strength parallel to the grain

In this test, we measure the compressive strength of the timber by applying the force parallel to the grain (see figure 1).
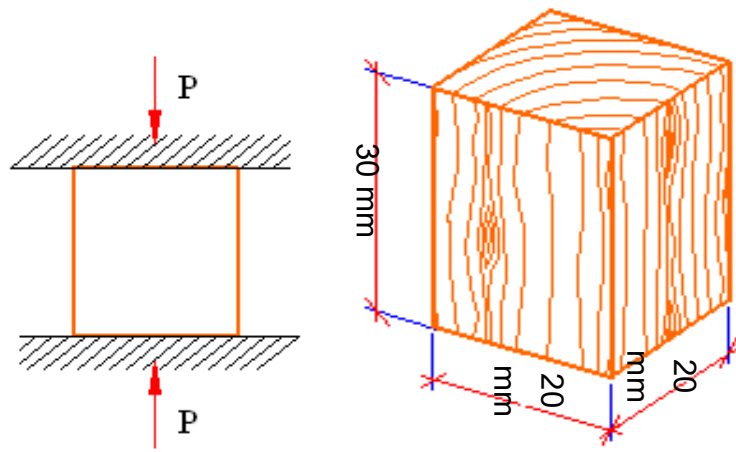

Fig.1. Compression test

2. Compressive strength perpendicular to grain

The second test, we measure the compressive strength of the timber perpendicular to the grain (see figure 2).
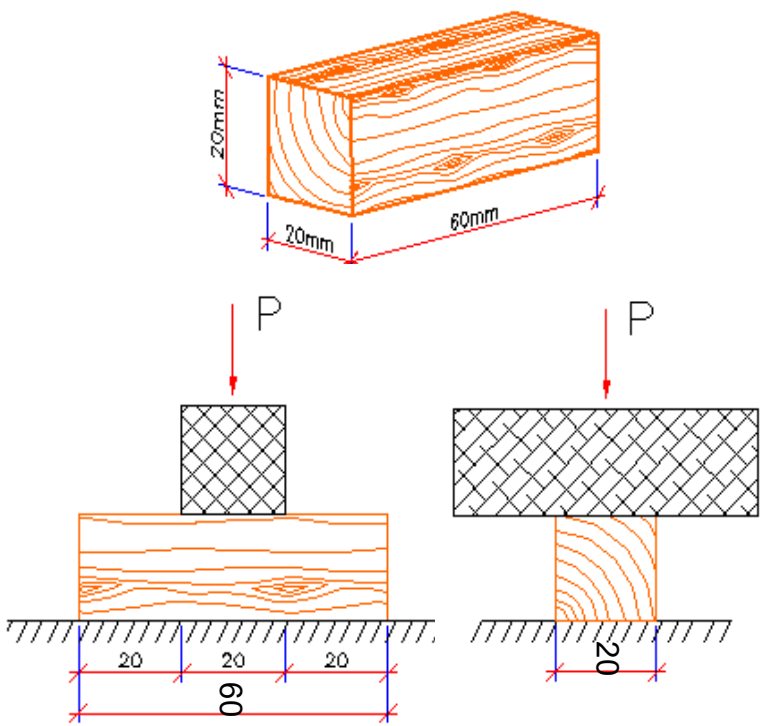

Fig.2. Compression perpendicular to the grain test

\section{Bending test}

In the bending mode timber is subjected to compression stresses on the upper part of the beam and tensile on the lower part. The Universal Testing Machine set up with two supports and the center-loading device as shown in the figure 3 . The samples were broken on a 3 points fixture with the load frame moving at $5 \mathrm{~N} / \mathrm{second}$.

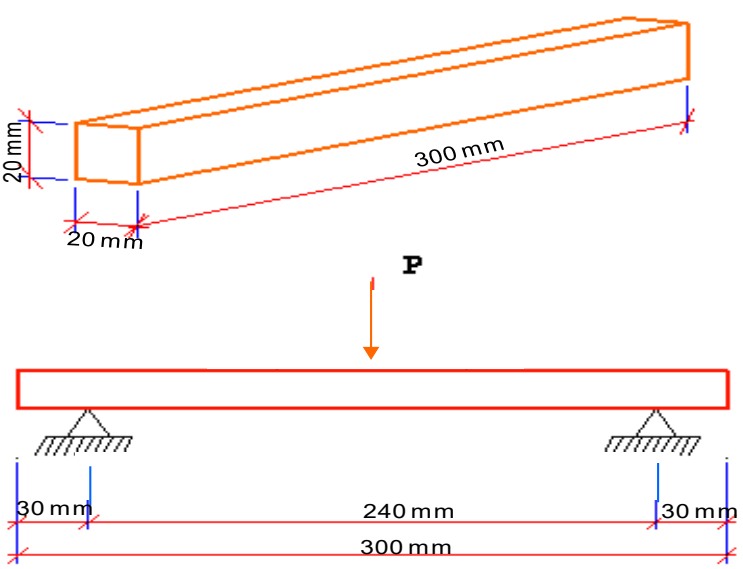

Fig.3. Bending test

4. Tensile strength perpendicular to the grain

Tensile strength perpendicular to the grain is a measure of the resistance of wood to forces acting across the grain which then to cause splits or cleavage. Strength of a specimen of wood in this respect is determined by measuring the force required to produce failure. Strength values measured in this manner are of use in estimating the resistance of wood to the splitting action of bolts and other fastenings. Figure 4 shows the shape of the sample. 

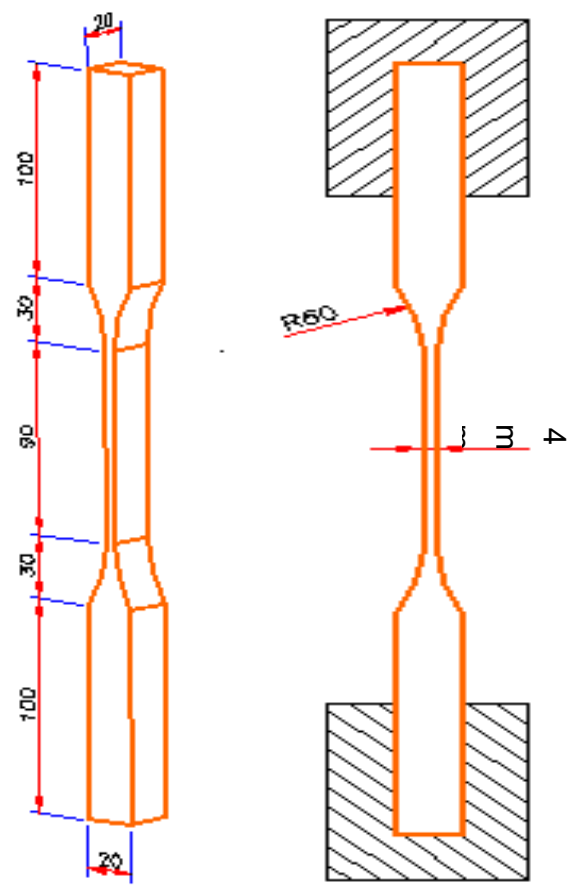

Fig.4. Tensile test

5. Shear strength

Figure 5 presents the sample shape for shear test.
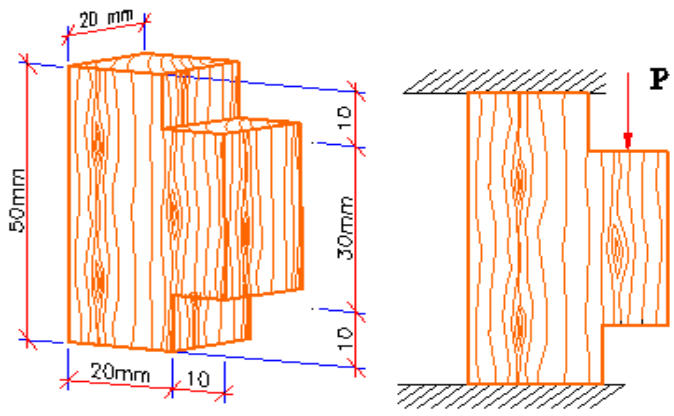

Fig.5. Shear test

\section{B. Testing machine}

In this research, all testing had been performed on a Universal Testing Machine Walter + Baiag, made in Switzerland (see figure 6).

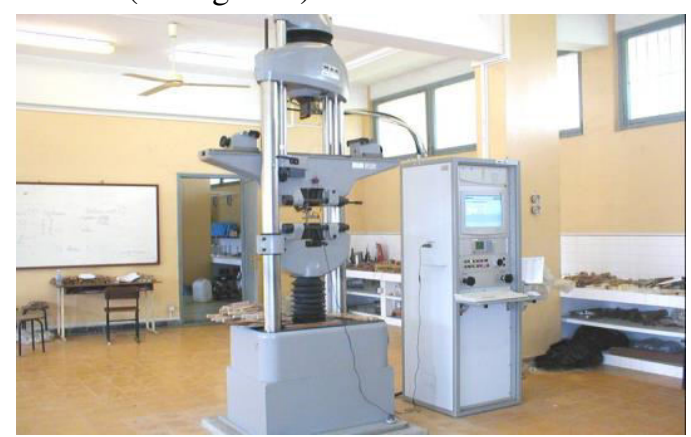

Fig.6. Testing machine

\section{Samples}

The samples are collected from almost all the provinces of Cambodia. About 46 species of timbers selected from 4 groups of wood are tested in the laboratory of Institute of Technology of Cambodia. The principle approach to the measurement of strength in timber is to assess the strength of small, knot-free, straight-grained samples $(20 \times 20) \mathrm{mm}$ in cross-section. The woods are cut into different shapes depend on different purpose of the tests (see figure7).

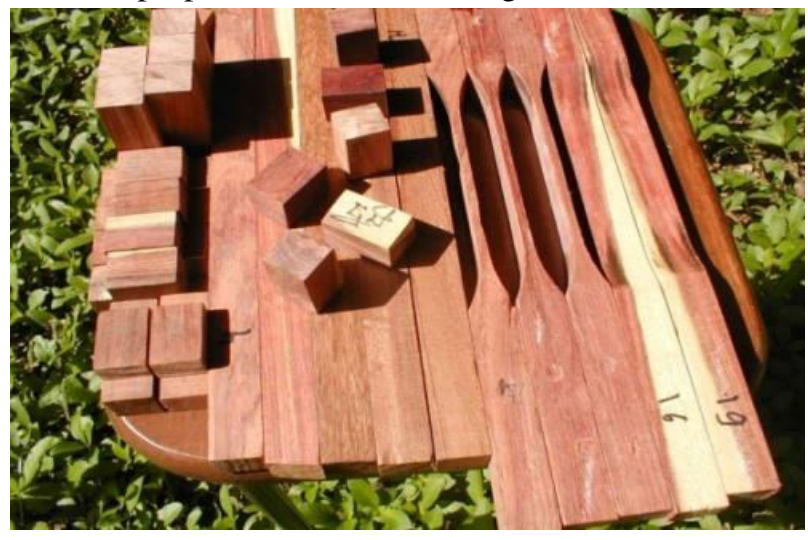

Fig.7. Samples cut into shapes (Pterocarpusindicus)

\section{RESULTS AND DISCUSSION}

We test about 46 species of timbers selected from 4 categories of wood. From the diagram results, it is found that when wood is loaded to higher stress levels beyond the elastic range, plastic deformation or failure occurs (see figure 8 ). In this study, five strength properties which are commonly used in design purposes are measured including compression parallel and perpendicular to the grain, bending, tension perpendicular to the grain, and shear parallel to the grain. Figure 8 presents the diagram results of Afzeliaxylocarpa. The results are listed in Table 1. 
The Third International Conference on Civil Engineering Research (ICCER) August $1^{\text {st }}-2^{\text {nd }} 2017$, Surabaya - Indonesia
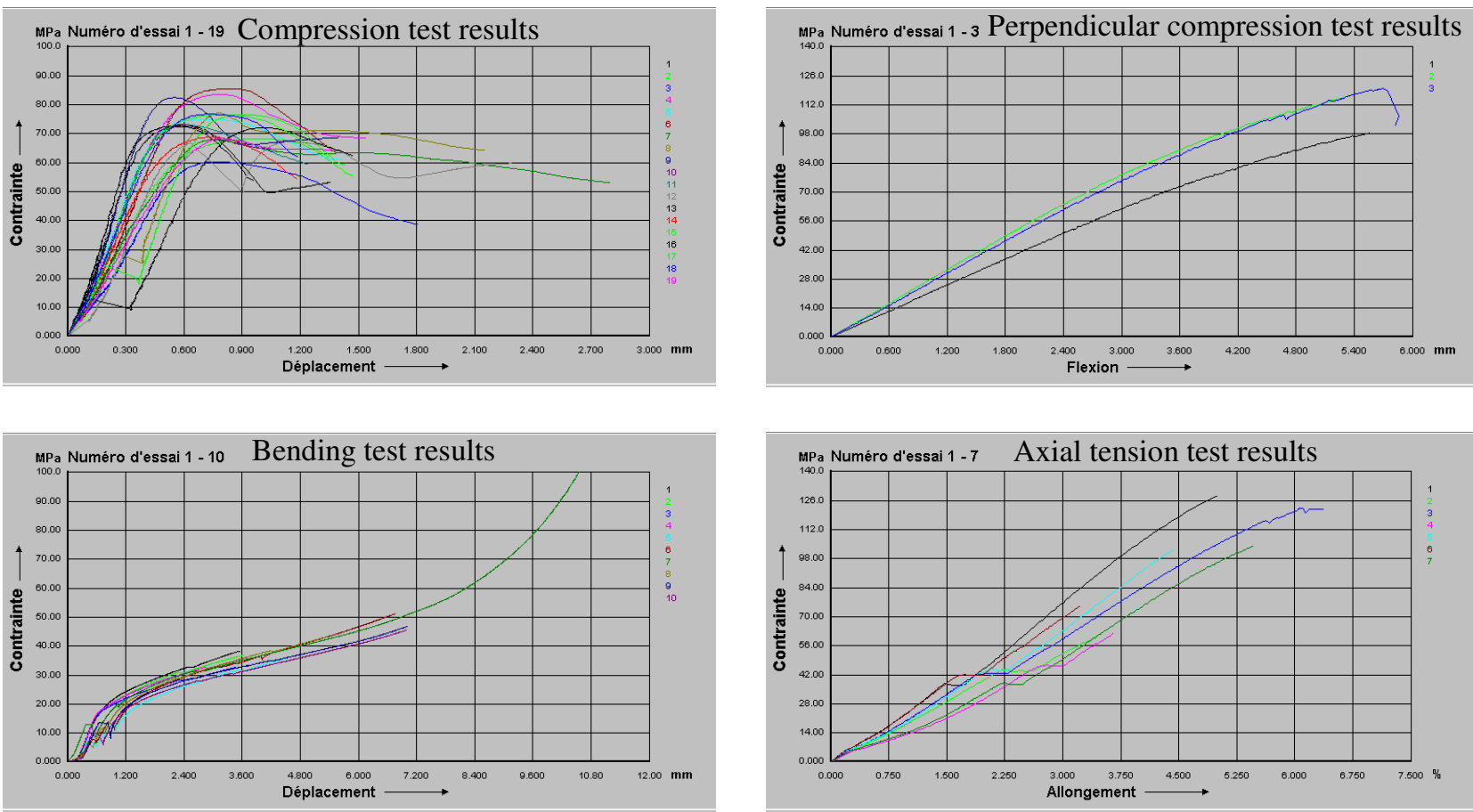

Fig.8. Diagram results of stress-strain

Table1. Mechanical Properties of Timbers

\begin{tabular}{|c|c|c|c|c|c|c|c|}
\hline \multicolumn{8}{|c|}{ Luxury Wood } \\
\hline $\begin{array}{l}\text { Cambodian } \\
\text { name }\end{array}$ & $\begin{array}{l}\text { Scientific name } \\
\text { Botanical name }\end{array}$ & $\begin{array}{l}\text { Density } \\
\left(\mathrm{T} / \mathrm{m}^{3}\right)\end{array}$ & $\begin{array}{l}\text { Axial } \\
\text { tension } \\
(\mathrm{MPa})\end{array}$ & $\begin{array}{c}\text { Axial } \\
\text { compression } \\
(\mathrm{MPa})\end{array}$ & $\begin{array}{c}\text { Bending } \\
\text { or } \\
\text { flexure } \\
\text { (MPa) }\end{array}$ & $\begin{array}{l}\text { Shear } \\
\text { (MPa) }\end{array}$ & $\begin{array}{l}\text { Perpendicular } \\
\text { compression } \\
\text { to the grain } \\
(\mathrm{MPa})\end{array}$ \\
\hline ebg, Béng & Afzelia xylocarpa & 0.8096 & 93.58 & 73.42 & 105.2 & 18.99 & 23.75 \\
\hline $\begin{array}{l}\text { RkjÚgQamman; } \\
\text { Kranhung }\end{array}$ & $\begin{array}{l}\text { Dalbergia } \\
\text { cochinchinensis }\end{array}$ & 1.09046 & 136 & 86.46 & 139.2 & 19.74 & 39.67 \\
\hline $\begin{array}{l}\text { nagnYn, } \\
\text { NeangNuon }\end{array}$ & $\begin{array}{l}\text { Dalbergia bariensis } \\
\text { Pierre }\end{array}$ & 1.0966 & 169.4 & 88.92 & 137.4 & 24.86 & 48.75 \\
\hline taRtav, Tatrav & Fagraea fragrans, Roxb. & 0.8491 & 101.1 & 58.45 & 85.67 & 13.95 & 20.68 \\
\hline Fñg;, Thnung & $\begin{array}{l}\text { Pterocarpus macrocarpus } \\
\text { Kurz }\end{array}$ & 0.8551 & 80.11 & 66.66 & 130.8 & 27.3 & 27.38 \\
\hline \multicolumn{8}{|c|}{ First Class Wood } \\
\hline $\begin{array}{c}\text { Cambodian } \\
\text { name }\end{array}$ & Scientific name & $\begin{array}{l}\text { Density } \\
\left(\mathrm{T} / \mathrm{m}^{3}\right)\end{array}$ & $\begin{array}{l}\text { Axial } \\
\text { tension } \\
(\mathrm{MPa})\end{array}$ & $\begin{array}{c}\text { Axial } \\
\text { compression } \\
(\mathrm{MPa})\end{array}$ & $\begin{array}{c}\text { Bending } \\
\text { or } \\
\text { flexure } \\
\text { (MPa) }\end{array}$ & $\begin{array}{l}\text { Shear } \\
\text { (MPa) }\end{array}$ & $\begin{array}{l}\text { Perpendicular } \\
\text { compression } \\
\text { to the grain } \\
(\mathrm{MPa})\end{array}$ \\
\hline $\begin{array}{l}\text { dYgEcm } \\
\text { Duong Chem }\end{array}$ & Heritiera javanica & 0.09425 & 139.9 & 54.51 & 104.9 & 21.35 & 19.38 \\
\hline KKIr/ KKIremSA & Hopea odorata & 0.7207 & 110 & 60.38 & 106.4 & 15.53 & 20 \\
\hline kekaH, Kokos & Sindora siamensis & 0.9272 & 106.3 & 70.69 & 104.3 & 3.21 & 45 \\
\hline
\end{tabular}


The Third International Conference on Civil Engineering Research (ICCER)

August $1^{\text {st }}-2^{\text {nd }} 2017$, Surabaya - Indonesia

Table1. Mechanical Properties of Timbers (cont.)

\begin{tabular}{|c|c|c|c|c|c|c|c|}
\hline \multicolumn{8}{|c|}{ First Class Wood } \\
\hline $\begin{array}{c}\text { Cambodian } \\
\text { name }\end{array}$ & Scientific name & $\begin{array}{l}\text { Density } \\
\left(T / \mathbf{m}^{3}\right)\end{array}$ & $\begin{array}{l}\text { Axial } \\
\text { tension } \\
(\mathrm{MPa})\end{array}$ & $\begin{array}{c}\text { Axial } \\
\text { compression } \\
\text { (MPa) }\end{array}$ & $\begin{array}{c}\text { Bending } \\
\text { or } \\
\text { flexure } \\
\text { (MPa) }\end{array}$ & $\begin{array}{l}\text { Shear } \\
\text { (MPa) }\end{array}$ & $\begin{array}{c}\text { Perpendicular } \\
\text { compression } \\
\text { to the grain } \\
(\mathrm{MPa})\end{array}$ \\
\hline RkLaj; , Kralanh & $\begin{array}{l}\text { Dialium cochinchinensis } \\
\text { Pierre }\end{array}$ & 1.2703 & 109.2 & 101.2 & & 33.06 & 61.33 \\
\hline ém:sak; May Sak & $\begin{array}{l}\text { Tectona Grandis } \\
\text { Berrya cordifolia }\end{array}$ & 0.5635 & 93.65 & 58.42 & 91.94 & 16.44 & 11 \\
\hline BBUlf $\mu$, Popul & Vitex pinnata, Glabrata & 0.8219 & 133.6 & 70.54 & 124.2 & 17.91 & 20.33 \\
\hline BeBI, Popel & Hopea recopei Pierre & 0.7377 & 63.02 & 46.14 & 80.86 & 17.18 & 21.33 \\
\hline sMB $1 / 2$ r, Sampor & $\begin{array}{l}\text { Artocarpus } \\
\text { nitidustréculsubsp. } \\
\text { Lingnanensis }\end{array}$ & 0.8444 & & 71.4 & 120.2 & 26.36 & 36.07 \\
\hline suRkM, Sokrom & Xylia xylocarpa & 0.95 & & 72.39 & 138.5 & 19.8 & 28.3 \\
\hline RseLA, Sralao & Lagerstroemia calyculata & 0.7229 & & 59.02 & 101 & 18.47 & 20.37 \\
\hline Qølk, Chlik & Terminalia alata & 0.7005 & 87.08 & 61.61 & 115.1 & 21.91 & 23.13 \\
\hline pw@k, Phchek & Shorea obtusa & 1.0361 & 118.1 & 65.41 & 141.8 & 22.51 & \\
\hline Rtesk, Trosek & $\begin{array}{l}\text { Peltophorum } \\
\text { dasyrrhachis }\end{array}$ & 0.7755 & 110.5 & 54.4 & 94.42 & 15.22 & 16.75 \\
\hline \multicolumn{8}{|c|}{ Second Class Wood } \\
\hline $\begin{array}{c}\text { Cambodian } \\
\text { name }\end{array}$ & Scientific name & $\begin{array}{l}\text { Density } \\
\left(T / m^{3}\right)\end{array}$ & $\begin{array}{l}\text { Axial } \\
\text { tension } \\
(\mathrm{MPa})\end{array}$ & $\begin{array}{c}\text { Axial } \\
\text { compression } \\
(\mathrm{MPa})\end{array}$ & $\begin{array}{c}\text { Bending } \\
\text { or } \\
\text { flexure } \\
\text { (MPa) }\end{array}$ & $\begin{array}{l}\text { Shear } \\
\text { (MPa) }\end{array}$ & $\begin{array}{c}\text { Perpendicular } \\
\text { compression } \\
\text { to the grain } \\
(\mathrm{MPa})\end{array}$ \\
\hline $\begin{array}{l}\text { nagEp } ¥ \mathrm{k} \\
\text { NeangPhaek }\end{array}$ & Dehaasia cuneatablume & 0.7513 & 114.3 & 58.85 & 105.4 & 19.79 & 17.75 \\
\hline $\begin{array}{l}\text { eQITal } \\
\text { Cheu Teal }\end{array}$ & Dipterocarpus alatus & 0.7818 & 98.47 & 58.6 & 88.27 & 19.92 & 17.83 \\
\hline $\mathrm{C} 1 / 2$ rcugChorchon & Shorea -guiso, blume & 1.0209 & 42.15 & 54.3 & 87.93 & & 31.67 \\
\hline xøúg, Khlong & $\begin{array}{l}\text { Depterocarpus } \\
\text { Tuberculatus }\end{array}$ & & & & 96.76 & 15.99 & \\
\hline IMe)ar, Lombor & $\begin{array}{l}\text { Shorea } \\
\text { farinose,Anisoptera }\end{array}$ & 0.8485 & 190.4 & 74.07 & 115 & 22.21 & 25.88 \\
\hline Et,g, Thbeng & $\begin{array}{l}\text { Diterocarpus } \\
\text { Obtusifolius }\end{array}$ & 0.6952 & 92.42 & 50.46 & 98.33 & 9.5 & 15.67 \\
\hline Rtac, Trach & Dipterocarpus intricatus & & 180.3 & & 109.4 & 23.6 & 19.5 \\
\hline xVav, Khvav & Haldina cordifolia & 0.7011 & 109.6 & 44.32 & 60.39 & 18.12 & 12.7 \\
\hline
\end{tabular}


Regional Conference in Civil Engineering (RCCE)

The Third International Conference on Civil Engineering Research (ICCER)

August $1^{\text {st }}-2^{\text {nd }}$ 2017, Surabaya - Indonesia

Table1. Mechanical Properties of Timbers (cont.)

\begin{tabular}{|c|c|c|c|c|c|c|c|}
\hline \multicolumn{8}{|c|}{ Third Class Wood } \\
\hline $\begin{array}{c}\text { Cambodian } \\
\text { name }\end{array}$ & Scientific name & $\begin{array}{c}\text { Density } \\
\left(T / \mathbf{m}^{3}\right)\end{array}$ & $\begin{array}{l}\text { Axial } \\
\text { tension } \\
(\mathrm{MPa})\end{array}$ & $\begin{array}{c}\text { Axial } \\
\text { compression } \\
(\mathrm{MPa})\end{array}$ & $\begin{array}{c}\text { Bending } \\
\text { or } \\
\text { flexure } \\
\text { (MPa) }\end{array}$ & $\begin{array}{l}\text { Shear } \\
\text { (MPa) }\end{array}$ & $\begin{array}{c}\text { Perpendicular } \\
\text { compression } \\
\text { to the grain } \\
(\mathrm{MPa})\end{array}$ \\
\hline kpúl, Khdol & Nauclea orientalis & & 32.74 & 27.3 & 43.76 & & \\
\hline kMBlgraC & Sandoricum koetjape & 0.5224 & 87.57 & 31.18 & 67.75 & 16.54 & 15.67 \\
\hline p¥úg, Phaong & Callophyllum pisiferum & 0.5341 & 91.35 & 41.57 & 83.72 & 15.85 & 9.9 \\
\hline suac;, Smach & Melaleucacajeputipowell & 0.6968 & 128.9 & 46.12 & 94.69 & 19.1 & 13.83 \\
\hline sVay, Svav & Mangifera indica & 0.5599 & & 44.99 & 68.02 & 12.91 & 8.25 \\
\hline Føk, Thlork & $\begin{array}{c}\text { Parinari annamensis } \\
\text { Hance }\end{array}$ & 0.8902 & 36.22 & 58.78 & & 14.8 & 19.5 \\
\hline RTEmg,Tromeng & Carallia brachiata & 0.7822 & 102.6 & 56.26 & 102.6 & 19.84 & 25 \\
\hline layPUvaMg & Alaia spectabilis & & 89.33 & 51.13 & 79.83 & 19.85 & 15.5 \\
\hline Rsl; , Sral & Pinus merkusii & 0.615 & & 39.3 & 62.88 & 17.02 & 10.13 \\
\hline KInIn, Kinin & Limonia acidissima L. & 0.759 & 52.58 & 45.28 & 100.7 & 20.73 & 17.33 \\
\hline RKab;Ebk & Swintonia pierreihance & 0.6516 & 43.89 & 40.07 & 70.2 & 20.03 & 25 \\
\hline xVit, Khvet & & & 141.3 & & 78.88 & 21.29 & \\
\hline Inút, Lomot & Manilkarazapota & & 166.6 & & 114.6 & 22.1 & \\
\hline xñúr, Khnol & $\begin{array}{c}\text { Artocarpus } \\
\text { heterophyllus lam. }\end{array}$ & 0.6612 & & 39.48 & 80.7 & 17.75 & 17 \\
\hline ekAs‘U, Caosou & Heveabrasiliensis & 0.615 & 104.3 & 46.26 & & 24.09 & 15 \\
\hline GMBil)araMg & $\begin{array}{c}\text { Albiziasaman (jack), f. } \\
\text { Muell. }\end{array}$ & 0.5318 & 66.55 & 30.21 & 61.86 & 17 & 11.33 \\
\hline RtEbk & Psidiumguajava & & 99.71 & & & 17.12 & \\
\hline Kr, Kor & Ceibapentandra & & 9.974 & 6.157 & 12.67 & & 4.8 \\
\hline exVH, Kve & & 0.4406 & & 33.27 & 49.42 & 13.25 & 5.81 \\
\hline $\begin{array}{l}\text { suac;eTs, Smach } \\
\text { Tes }\end{array}$ & Acasia auriculiformis & & 75.95 & 49.83 & 85.66 & 17.21 & 28.33 \\
\hline
\end{tabular}




\section{CONCLUSION}

From the results of these experiments, it found that the unit weight of lumbers is very different from one species to another. It can be observed that as the density increases, the various strength properties also increase. Some timbers resist very well under the ground like PHCHEK (Shorea Obtusa in first class of wood). Some others resist in water than others, for example KOKI (Hopea Odorata in the first class of wood). The mechanical properties of timbers are summarized in table1.

To the author's knowledge, this research could help students, researchers, construction companies and architects to design and construct wood construction projects more economically, safely and appropriately. The results of this project will be shared with other researchers in different institutions within the region, and will be helpful for them in terms of field of construction.

The further study will be developed and determined the strength standard of timbers in Cambodia.

\section{ACKNOWLEDGMENT}

The author would like to thank JICA for their project of Southeast Asia Engineering Education Development Network (SEED-Net) for the financial support. The author would also like to express gratitude to the staffs of laboratory of Civil Engineering Department of the Institute of Technology of Cambodia (ITC) for the experimental tests.

\section{REFERENCES}

[1] S. A. Ung and V. Khun, "Country Report Cambodia," in Japan-Asia REDD Seminar, 2008.

[2] Pauline D.P., Plants used in Cambodia, 2000.

[3] J.M. Illston, Construction materials, E\&FNSPON, 1994.

[4] D.W. Green, Wood: strength and stiffness, 2001.

[5] Yale H.,Wood Structural Design Data,Vol.1., Third Edition, 1958. 